\title{
Morphological and radiographic parameters of facet joints and their dependence on the grade of intervertebral disc degeneration
}

\author{
A.E. Krivoshein ${ }^{1,3}$, V.P. Konev ${ }^{1}$, S.V. Kolesov ${ }^{2}$, S.N. Moskovsky¹, Yu.T. Ignatiev ${ }^{1}$, S.A. Nikitenko ${ }^{1}$, \\ S.A. Erofeev ${ }^{1,3}$ \\ ${ }^{1}$ Omsk State Medical University, Omsk, Russian Federation \\ ${ }^{2}$ National Medical Research Center of Traumatology and Orthopedics n.a. N.N. Priorov, Moscow, Russian Federation \\ ${ }^{3}$ Clinical medical and surgical center of the Ministry of health of Omsk region, Omsk, Russian Federation
}

\begin{abstract}
Objective To study morphological and radiological parameters of facet joints depending on the grade of the intervertebral disk degeneration. Materials and methods To study the facet joints of the lumbar spine in 145 patients with various grades of degeneration according to Pfirrmann and treated using rigid fixation and TLIF technology, MSCT in 2-energy mode and morphological investigation of the intraoperative material were performed. Results In Pfirrmann grade 2 , an increase in the volumetric content of chondrocytes, Hounsfield density of the cartilage plate, and the level of Ca in the facet joints was visualized. They indicate that the joint remains functional. In Pfirrmann grade 5, deep pathological changes occurred with violation of the architectonics of the cartilage formations of the facet joints, formation of bone elements and connective tissue growth into the cartilage and bone structures of the joint, which correlated with the results of MSCT. Conclusion The data obtained show that there is a close relationship between morphological and radiological changes in the facet joints. Modulating the data obtained allows us to obtain objective criteria for evaluating the grade of pathological processes in facet joints and use them as a diagnostic component when planning decompression and stabilizing operations in patients with degenerative diseases of the lumbar spine.
\end{abstract}

Keywords: disc degeneration, facet joint, adjacent disc, MSCT, morphology

\section{INTRODUCTION}

Degenerative diseases of the spine, including those accompanied by chronic pain, are a complex problem that requires multidisciplinary approach and multimodality therapy [1]. This pathology affects persons of working age and has high risks of primary disability and significant financial costs [2].

Pain in the lumbar spine is mainly associated with degeneration of intervertebral discs, facet joints, or a combination of both [3]. At the same time, their pathological processes do not always run in parallel, and therefore detailed preoperative characteristics of the pathomorphological substrate and an assessment of the severity of degenerative changes in the structures of the spinal motor segment (SMS) are necessary to determine the correct method and type of surgical treatment [4].

The most widespread treatments are decompression and stabilization interventions using rigid systems for fixing the spinal motion segment (SMS). Unsatisfactory results of such surgical interventions, primarily associated with the development of the adjacent segment syndrome and postoperative instability, stimulate researchers to search for the main reasons that determine the development of complications $[5,6,7]$. The adjacent disc syndrome is associated with an increased load on the facet joints (FJ) and intervertebral discs of the adjacent level. Particular attention is paid to the condition of the facet joints when using various options for dynamic fixation of the spine, namely, the grade of joint degeneration (according to Fujiwara), "tropism of the facet joints" and the facet angle index, as well as the grade of disc degeneration (according to Pfirrmann) $[8,9]$.

One of the optimal methods for assessing the structures of the spinal motion segment is computed tomography, especially dual-energy tomography (DECT), which has become widespread in the recent years $[10,11]$.

There are no scientific publications devoted to modulation of morphological and radiographic parameters of the facet joints depending on the grade of intervertebral disc degeneration. Moreover, the impact of facet arthrosis on segment instability and development of adjacent disc syndrome under various fixation methods of SMS have not been shown.

Purpose To study the morphological and radiographic parameters of the facet joints, depending on the grade of intervertebral disc degeneration.

Krivoshein A.E., Konev V.P., Kolesov S.V., Moskovsky S.N., Ignatiev Yu.T., Nikitenko S.A., Erofeev S.A. Morphological and radiographic parameters of facet joints and their dependence on the grade of intervertebral disc degeneration. Genij Ortopedii, 2020, vol. 26, no 4, pp. 565-570. DOI 10.18019/1028-4427-2020-26-4-565-570 


\section{MATERIAL AND METHODS}

From January 2017 to December 2018, 145 interventions for degenerative diseases of the lumbar spine were performed at the Department of Traumatology No. 2 (Vertebrology) of the Clinical medical and surgical centre of the ministry of health of Omsk region. The study was conducted in accordance with the Declaration of Helsinki of the World Medical Association on ethical principles for conducting medical research with human participation as amended in 2000 and the "Rules of Clinical Practice in the Russian Federation" approved by the Order of the Ministry of Health of the Russian Federation of June 19, 2003 No. 266. The research was approved by the ethics board of the Omsk State Medical University. All persons participating in the study, or their legal representatives, signed an informed consent to participate and publish data without personal identification. The study was carried out within the framework of the state assignment for research work No AAAA-A18 118011190073-0 of January 11, 2018.

The criteria for inclusion in the study groups were:

- ineffective conservative therapy;

- long-term recurrent pain;

- persistent neurological deficit;

- absence of signs of segment instability;

- one-level and two-level disc degeneration of grades II - V (Pfirrmann) according to MRI.

The exclusion criteria were:

- spondylolisthesis with spondylolysis;

- the need for significant correction of the sagittal balance;

- advanced osteoporosis.

The study included 145 patients who, after having had a complex clinical and instrumental examinations, underwent decompression and stabilization interventions on the lumbar spine. Transpedicular fixation of the SMS, complete and partial facetectomy at the lesion level and posterior interbody fusion with cage technology (TLIF) were performed. The material harvested was subjected to morphological study.

On the basis of MRI findings, all morphologically examined facet joints were divided into four groups depending on the grade of disc degeneration according to Pfirrmann. Thirty-one cases were attributed to the Pfirrmann group of grade-II disc degeneration, 36 to the Pfirrmann group III of degeneration grade, 46 to the Pfirmann group IV and 32 cases to Pfirrmann group V.

Morphological study was conducted at the Department of Forensic Medicine of Omsk State Medical University. The material obtained intraoperatively was fixed in $10 \%$ neutral formalin. Subsequently, the material was subjected to decalcification in $0.1 \mathrm{~N}$. hydrochloric acid solution based on saline. After decalcification, the samples passed through alcohols of ascending density and embedded in paraffin. Paraffin media were stained with hematoxylin and eosin, picrofuchsin according to Van Gieson. The preparations were studied with light microscopy, and, if necessary, examination and digital microphotography were conducted with NuLife Sciences microscope. Standard morphometry revealed calculation and measured signs.

Radiographic study was performed at Clinical Diagnostic Centre and at the Department of Radiation Diagnosis of Omsk State Medical University. MSCT examination was done in all patients at the stage of preoperative planning. MSCT of the lumbar spine was performed in dual-energy mode on a GE Discovery $750 \mathrm{HD}$ device prior to surgery in the mode of submillisecond switching of 80 and $120 \mathrm{kV}$ voltage at a constant current of $450 \mathrm{~mA}$. Scanning was performed with $0.625 \mathrm{~mm}$ slices followed by multiplanar reconstruction. The indicators of degenerative changes were assessed on the basis of the regular X-ray manifestations of this process in the spinal motion segment with dual-energy scanning. A quantitative X-ray morphometric assessment of the FJ was performed in the affected area; density of the subchondral region (the density of the outer and inner facets) and the area of the cartilaginous plate of the $\mathrm{FJ}$ was measured in Hounsfield units (HU) and calcium (Ca) level per one cubic centimeter (Fig. 1).

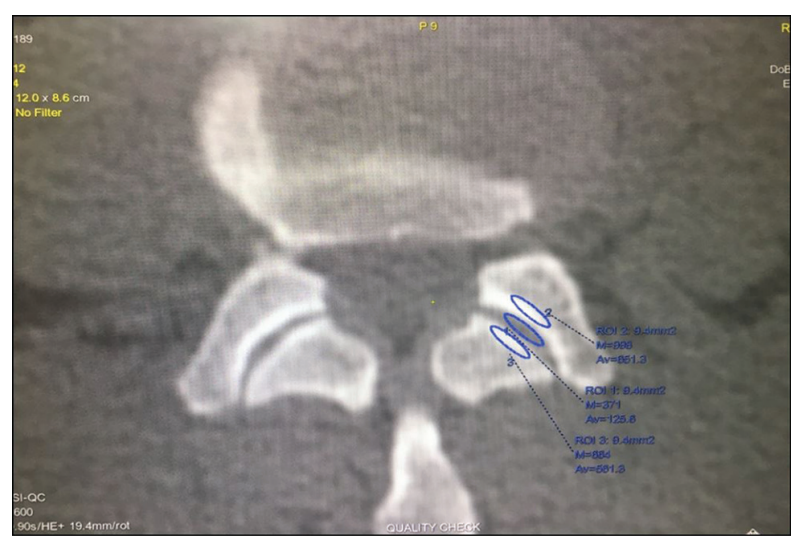

Fig. 1 Technique for quantitative assessment of FJ tissue density in HU units and $\mathrm{Ca}$ level per $\mathrm{cm} 3$ in the involved zone, axial projection of the affected SMS

Statistical processing of the obtained data was carried out by the methods of variation statistics using standard packages Microsoft Excel 2008, Statistica 12.0, Biostat. The database was created with MS Excel spreadsheet editor, 1C. In the case of a distribution other than normal, nonparametric tests were used. Statistical measurement of the relationship (strength and direction) between the signs was carried out by calculating the correlation coefficient of Spearman's ranks (rs), followed by an assessment of diagnostic significance (criteria of information content: sensitivity (Se) and specificity (Sp)).

The sample size was calculated using the Lehr formula for a power of $80 \%$ and a two-sided significance level of 0.05 .

\section{RESULTS}

Morphological analysis of the surgical material in the Pfirrmann II group detected initial signs of pathological bone regeneration such as solitary ingrowths of bone trabeculae from the subchondral layers of the facet joint bone towards the cartilaginous plate (Fig. 2 a). Active regeneration of chondrocytes in the deep layers of the cartilaginous plate ran in the proximity of bone trabeculae in 28 samples of this group. A statistically significant increase in the volumetric content of chondrocytes in the superficial zone of the cartilage (Table 1) was revealed due to an increase in three- and four-cell lacunae along with a simultaneous decrease in 
the number of unicellular lacunae, which indicates the activation of reparative processes.

Radiographic study (DECT) in patients of this group showed the density measuring $154.8 \pm 14.3 \mathrm{HU}$ in the cartilaginous plate, $713.65 \pm 83.65 \mathrm{HU}$ in the outer facet and 582.1 $\pm 65.1 \mathrm{HU}$ the inner facet (Fig. $2 \mathrm{~b}$ ).

In 31 cases of the Pfirrmann group III, due to an increase in the load on the joints involved, morphological signs of an increase in trabecular bone ingrowths (pathological regeneration) both in number and in depth were revealed. They led to a change in the topographic architectonics at the border of the cartilage and bone (Fig. 3 a). Chondrocyte regeneration was similar in all layers of the cartilaginous plate and had a tendency to decrease (Table 1). In the bone structures of the FJ, a significant increase in the diameter of the Haversian canals was revealed along with an increased number of vascular invasions, which indicated a compensatory increased nutrition of the joint.

According to DECT, a significant increase in the density of all FJ components was revealed in this group: the density of the cartilaginous plate increased to $237 \pm 43.5 \mathrm{HU}$, of the outer facet up to $828.55 \pm 100 \mathrm{HU}$, and in the inner facet up to $716.4 \pm 140.8 \mathrm{HU}$ (Fig. $3 \mathrm{~b}$ ).

Morphological analysis of the surgical material in the Pfirrmann IV group showed active growth of bone trabeculae (pathological bone regeneration) which replaced the cartilaginous plate throughout its extension. Morphometrically, there was a significant increase in the volumetric content of chondrocytes in the intermediate

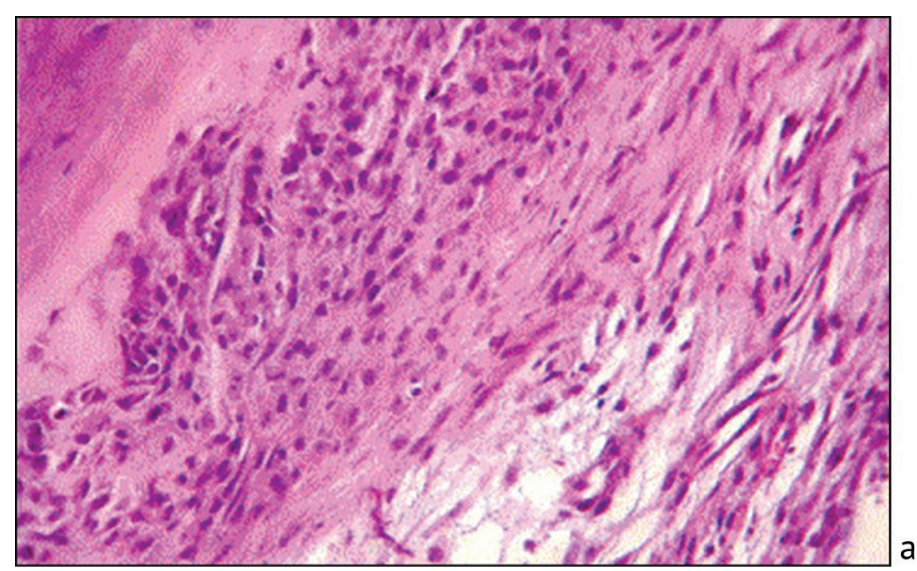

zone due to an increase in the number of two- and three-cell lacunae (Table 1) and a decrease in the volumetric density of cells in the cartilaginous plate, which indicated its thinning. At the same time, the number of vessels and the diameter of the Havers canals in the bone structures of the FJ continued to grow along with the signs of connective tissue invasion into the cartilaginous and bone structures of the facet joint, which indicated a persistent malnutrition of the cartilage, sclerosis of the articular surfaces and, as a consequence, the changing density of FO components (Fig. 4 a). The results correlated with the results of FJ density obtained with DECT: the density of the cartilaginous plate slightly decreased in comparison with the Pfirrmann group III and amounted to $208.1 \pm 22.1 \mathrm{HU}$, and the density of the outer and inner facets increased to $903.1 \pm 96.9 \mathrm{HU}$ and $808.7 \pm 91 \mathrm{HU}$, respectively (Table 1).

Morphological study in Pfirmann group $\mathrm{V}$ revealed deep pathological outgrowth of bone trabeculae with the formation of full-fledged bone elements along the entire extension of the cartilaginous plate. In the intertrabecular spaces, solitary defective cartilage zones were still present, in which two- and three-cell lacunae were accumulated. Connective tissue grew into the cartilaginous and bone structures of the FS, as in the previous group, which did not allow visualization of clear boundaries between the bone and cartilage tissue (Fig. 5, a). According to morphometry data, significant vascular growth and an increase in the diameter of the Haversian canals were established in the FS bone elements (Table 1).

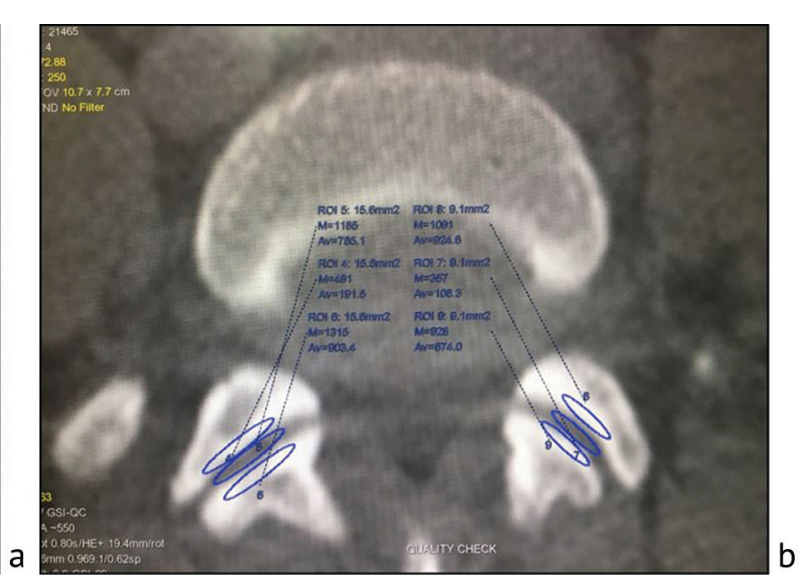

Fig. 2 Morphological and radiographic pictures of facet joints in the affected area, Pfirrmann group II: $\boldsymbol{a}$ active regeneration of chondrocytes in the deep layers, single ingrowth of bone trabeculae. Staining with hematoxylin and eosin; $\times 180 ; \boldsymbol{b}$ axial projection of SMS in the affected area (MSCT in dual-energy mode)
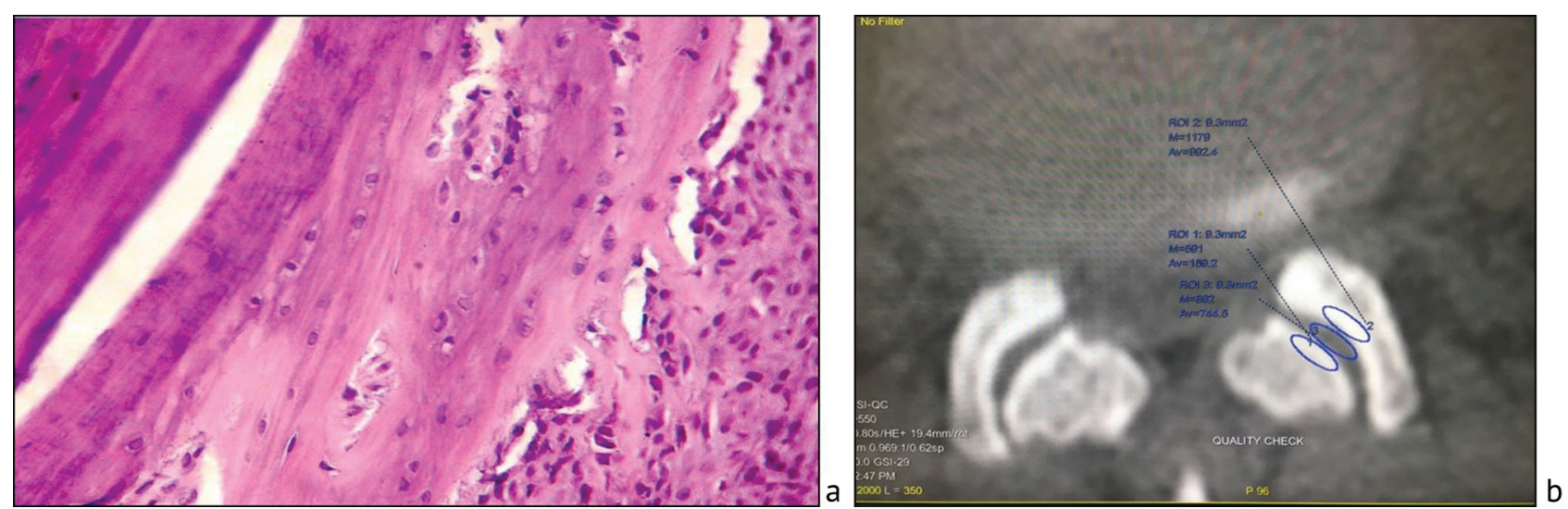

Fig. 3 Morphological and radiographic pictures of the facet joints in the affected area, Pfirrmann group III: $\boldsymbol{a}$ an increase in bony ingrowth in depth and number. Staining with hematoxylin and eosin; $\times 180 ; \boldsymbol{b}$ axial projection of SMS in the affected area (MSCT in dual-energy mode) 
Table 1

Evaluation of morphological and radiological criteria in various grades of intervertebral disc degeneration according to Pfirrmann

\begin{tabular}{|c|c|c|c|c|c|c|c|}
\hline \multirow{2}{*}{ Criteria } & \multirow{2}{*}{ Group II } & \multirow{2}{*}{ Group III } & \multirow{2}{*}{ Group IV } & \multirow{2}{*}{ Group V } & \multirow{2}{*}{$\begin{array}{c}\text { Informativeness, } \\
\mathrm{J}\end{array}$} & \multirow{2}{*}{$\begin{array}{l}\mathrm{Se} \\
\%\end{array}$} & \multirow{2}{*}{\begin{tabular}{|c|}
$\mathrm{Sp}$ \\
$\%$ \\
\end{tabular}} \\
\hline & & & & & & & \\
\hline Cartilaginous plate density, HU (DECT) & $154.8 \pm 14.2$ & $237 \pm 43.5$ & $208.1 \pm 22.1$ & $*$ & 0.54 & 92.2 & 91.0 \\
\hline Outer facet density, HU (DECT) & $713.65 \pm 83.65$ & $828.55 \pm 110.9$ & $903.1 \pm 96.9$ & $962.2 \pm 126.8$ & 0.6 & 94.1 & 92.6 \\
\hline Inner facet density, HU (DECT) & $582.1 \pm 65.1$ & $716.4 \pm 140.8$ & $808.7 \pm 91.3$ & $867.6 \pm 49.4$ & 0.46 & 32.5 & 98.72 \\
\hline Cartilaginous plate, $\mathrm{mg} \mathrm{Ca}$ in $1 \mathrm{~cm}^{3}$ & $76.8 \pm 12.2$ & $111.8 \pm 33.2$ & $117 \pm 38.1$ & * & 0.54 & 92.2 & 91.0 \\
\hline Outer facet, $\mathrm{mg} \mathrm{Ca}$ in $1 \mathrm{~cm}^{3}$ & $239.2 \pm 52.2$ & $278.8 \pm 37.4$ & $313.3 \pm 35.7$ & $*$ & 0.47 & 89.1 & 85.4 \\
\hline Inner facet, $\mathrm{mg} \mathrm{Ca}$ in $1 \mathrm{~cm}^{3}$ & $223.4 \pm 13.4$ & $279.1 \pm 6.9$ & $293.2 \pm 23.2$ & $395.2 \pm 4.8$ & 0.51 & 91.7 & 90.4 \\
\hline Volumetric content of chondrocytes in the superficial zone & $19.85 \pm 0.14$ & $4.25 \pm 0.39$ & $4.1 \pm 0.33$ & $3.85 \pm 0.2$ & 0.38 & 85.6 & 85.28 \\
\hline Volumetric content of chondrocytes in the intermediate zone & $5.0 \pm 0.55$ & $3.98 \pm 0.40$ & $7.51 \pm 0.24$ & $6.2 \pm 0.34$ & 0.36 & 40.3 & 97.5 \\
\hline Volumetric content of chondrocytes in the deep zone & $4.58 \pm 0.49$ & $4.58 \pm 0.51$ & $4.02 \pm 0.19$ & $4.35 \pm 0.40$ & 0.46 & 32.5 & 98.72 \\
\hline Mean number of Haversian canals in the vision field & $6 \pm 0.30$ & $4.5 \pm 0.60$ & $5 \pm 0.60$ & $4.8 \pm 0.3$ & 0.26 & 31.2 & 98.21 \\
\hline Mean number of vessels in the field of vision & $18 \pm 0.90$ & $16 \pm 2.01$ & $24 \pm 2.01$ & $28 \pm 1.7$ & 0.42 & 37.7 & 98.08 \\
\hline Mean diameter of Haversian canals & $2.01 \pm 0.01$ & $3.60 \pm 0.50$ & $4.30 \pm 0.50$ & $4.8 \pm 0.50$ & 0.36 & 40.3 & 97.5 \\
\hline
\end{tabular}

Note: $*$ - no reliable data due to the vacuum effect
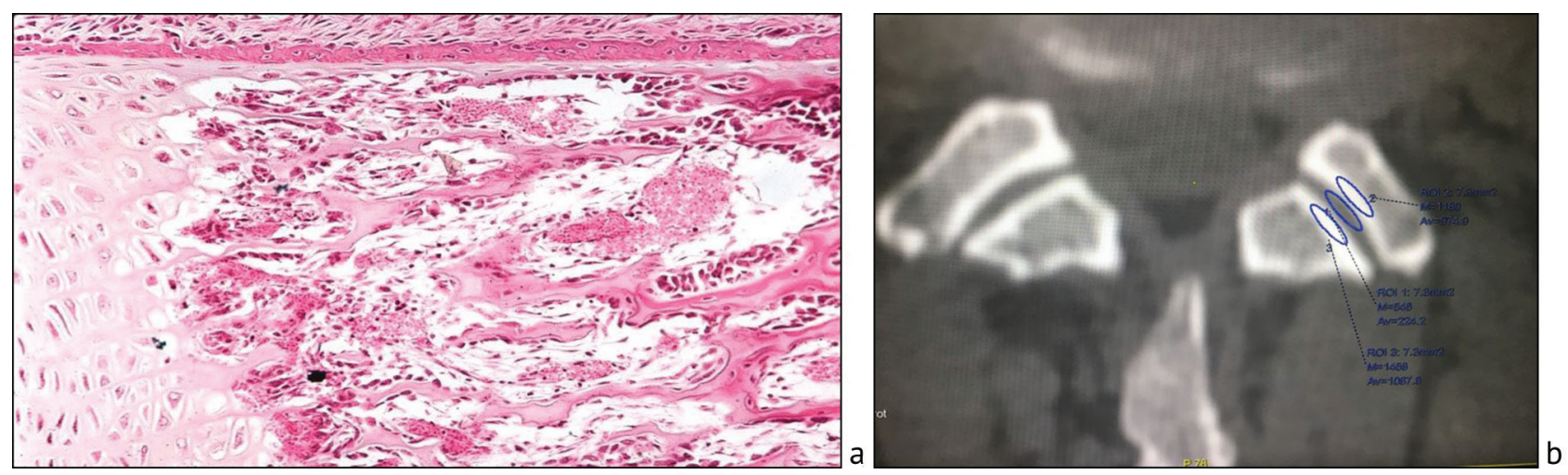

Fig. 4 Morphological and radiological picture of facet joints in the affected area, Pfirrmann group IV: $\boldsymbol{a}$ active ingrowth of bone trabeculae, invasion of connective tissue into cartilaginous and bone structures of the facet joint. Staining with hematoxylin and eosin; $\times 180 ; \boldsymbol{b}$ axial projection of the SMS in the affected area (MSCT in dual-energy mode)
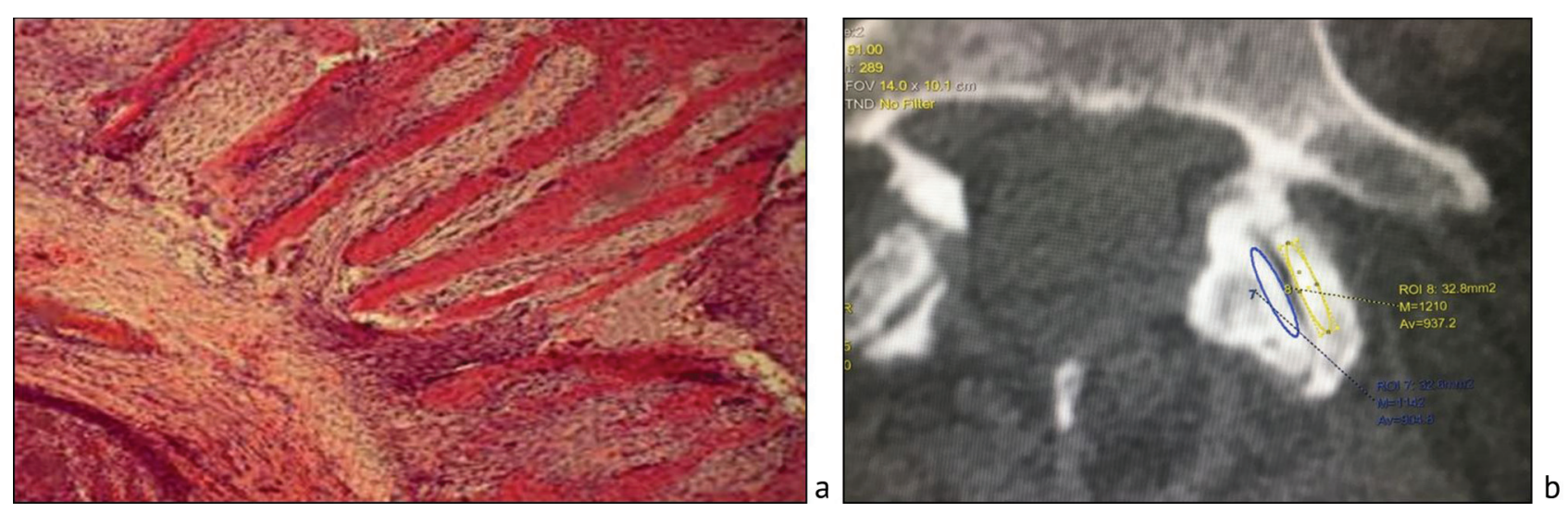

Fig. 5 Morphological and radiographic pictures of facet joints in the affected area, Pfirrmann V group: $\boldsymbol{a}$ defective cartilaginous zones and deep pathological bony outgrowth. Staining with hematoxylin and eosin; $\times 180 ; \boldsymbol{b}$ axial projection of the SMS in the affected area (MSCT in dual-energy mode)

The DECT study in the group $\mathrm{V}$ showed the following results: the density of the cartilaginous plate was $0 \mathrm{HU}$ which corresponded to the vacuum effect, the outer facet was $962.2 \pm 12.6 \mathrm{HU}$, and the inner facet was $867.6 \pm 49 \mathrm{HU}$.

Thus, the morphological studies showed a significant increase in the volumetric content of chondrocytes in the initial manifestations of degeneration while the joint functionality was maintained. It was found that with an increase in the grade of disc degeneration, the volumetric content of chondrocytes significantly decreased, the microarchitectonics were restructured including due to the invasion of connective tissue into the structural FJ components. It led to a change in the thickness of the articular cartilage, sclerosis, and disruption of the relationship between the cartilaginous and bone structures of the facet joint, directed towards ankylosing and, accordingly, to dysfunction of the joint, which correlated with the results of DECT. Cartilage plate density indices according to $\mathrm{CT}$ data in the 
Pfirrmann II group were $154.8 \pm 14.2 \mathrm{HU}$, and in the Pfirrmann V group they increased to $208.1 \pm 22.1 \mathrm{HU}$. The same pattern was observed when studying the $\mathrm{Ca}$ level in the cartilaginous plate. Depending on the grade of disc degeneration according to Pfirrmann, the $\mathrm{Ca}$ level increased from $76.8 \pm 12.2$ to $117 \pm 38.1$ in $1 \mathrm{~cm}^{3}$, which confirms the results of morphological studies (Table 1).

\section{DISCUSSION}

Despite the fact that various options for dynamic fixation of the SMS have been actively used in spinal surgery for many years, operations using rigid fixation systems (either TLIF or PLIF) still remain the "gold standard" of surgical treatment of patients with degenerative diseases of the lumbar spine [12 ].

To determine the tactics of surgical treatment, the existing methods of neuroimaging of degenerative diseases of the lumbar spine, according to the literature [3], are based on the method of diffuse-weighted MRI diagnosis. It allows, based on pathomorphological analysis, to clearly determine the severity of intervertebral disc degeneration. Similarly, there is a classification of facet joint degeneration of A. Fujiwara et al., based on MRI diagnosis which correlates with the stages of joint degeneration according to the OARSI classification $[13,14]$. In our opinion, this approach to the interpretation of pathology does not fully reflect the entire nature of pathomorphological changes and architectonics in the FJ structure.

Currently, the issue of clinical efficacy and safety of the use of rigid and dynamic systems of fixation of the affected SMS in degenerative diseases of the spine remains debatable $[15,16]$. The available randomized clinical trials of patients with degenerative diseases of the lumbar spine are based on short-term periods of postoperative follow-up [17]. The ongoing search for pathogenetic concepts of the adjacent disc syndrome in the late postoperative period is based only on instrumental standard methods of neuroimaging [3, 13, 14], which do not allow obtaining an objective picture of the course of the pathological process.

A detailed study of the pathomorphological substrate in combination with the data of instrumental methods of neuroimaging of SMS affected by the degenerative process and adjacent disks is the basis for both choosing an effective surgical technique and evaluating the results of treatment of such patients in the long term.

Our complex morphological and instrumental study found an increased volumetric content of chondrocytes, density of the cartilaginous plate in $\mathrm{HU}$ units and $\mathrm{Ca}$ level in the SMS in Pfirrmann group II, which indicates the preservation of the functionality of the joint and allows the use of dynamic fixation as a surgical aid.

In a severe grade of disc degeneration in Pfirmann $\mathrm{V}$, deep pathological changes occurred in the FO along with a violation of the architectonics of all elements of the joint: formation of defective cartilaginous zones, formation of bone elements and connective tissue invasion into the cartilaginous and bone structures of the joint, which correlated with the results of DECT. In this grade, rigid fixation of the affected SMS is the method of choice. The DECT criteria for the state of FJ obtained might be used in a complex of patient studies to assess the grade of SMS degeneration in the affected area and adjacent segments to use in preoperative planning and prediction of treatment results.

\section{CONCLUSION}

The data obtained show that there is a close relationship between morphological and radiographic changes in the facet joints. Correlation of the data allows us to obtain objective criteria for evaluating the grade of pathological processes in the facet joints and use them as a diagnostic component when planning decompression and stabilizing operations in patients with degenerative diseases of the lumbar spine.

\section{Conflict of interests Athe authors declare that they do not have any conflict of interest.}

\section{REFERENCES}

1. Kolesov S.V., Kazmin A.I., Shvets V.V., Gushcha A.O., Poltorako E.N., Basankin I.V., Krivoshein A.E., Bukhtin K.M., Panteleev A.A., Sazhnev M.L., Pereverzev V.S. Sravnenie effektivnosti primeneniia sterzhnei iz nitinola i titanovykh sterzhnei pri khirurgicheskom lechenii degenerativnykh zabolevanii pozvonochnika s fiksatsiei poiasnichno-kresttsovogo otdela [The comparison of the effectiveness of using rods of nitinol and titanium rods for surgical treatment of the spine degenerative diseases with fixation of the lumbosacral spine]. Travmatologiia $i$ Ortopediia Rossii, 2019, vol. 25 , no. 2, pp. 59-70. (in Russian)

2. Byvaltsev V.A., Kalinin A.A., Stepanov I.A., Okoneshnikova A.K. Degenerativnye zabolevaniia dugootrostchatykh sustavov poiasnichnogo otdela pozvonochnika: diagnostika i khirurgicheskoe lechenie [Degenerative diseases of facet joints of the lumbar spine: diagnosis and surgical treatment]. Novosibirsk, Nauka, 2018, 208 p. (in Russian)

3. Byvaltsev V.A., Stepanov I.A., Kalinin A.A., Belykh E.G. Diffuzionno-vzveshennaia magnitno-rezonansnaia tomografiia v diagnostike degeneratsii mezhpozvonkovykh diskov poiasnichno-kresttsovogo otdela pozvonochnika [Diffusion-weighted magnetic resonance tomography in diagnosing intervertebral disc degeneration in the lumbosacral spine]. Vestnik Rentgenologii i Radiologii, 2016, vol. 97, no. 6, pp. 357-364. (in Russian)

4. Byvaltsev V.A., Kalinin A.A., Okoneshnikova A.K., Irintseev A.A. Differentsirovannaia khirurgicheskaia taktika pri degenerativnykh zabolevaniiakh poiasnichnogo otdela pozvonochnika s ispolzovaniem punktsionnykh metodik [Differentiated surgical tactics for degenerative diseases of the lumbar spine using puncture techniques]. Sibirskoe Meditsinskoe Obozrenie, 2018, no. 5, pp. 54-65. (in Russian)

5. Siepe C.J., Zelenkov P., Sauri-Barraza J.C., Szeimies U., Grubinger T., Tepass A., Stäbler A., Mayer M.H. The fate of facet joint and adjacent level disc degeneration following total lumbar disc replacement: a prospective clinical, X-ray, and magnetic resonance imaging investigation. Spine, 2010, vol. 35, no. 22, pp. 1991-2003. DOI: 10.1097/ BRS.0b013e3181d6f878

6. Simonovich A.E. Primenenie instrumentariia DYNESYS dlia dinamicheskoi fiksatsii poiasnichnogo otdela pozvonochnika pri ego degenerativnykh porazheniiakh [The use of DYNESYS instrumentarium for dynamic fixation of the lumbar spine for its degenerative disorders]. Khirurgiia Pozvonochnika, 2004, no. 1, pp. 60-66. (in Russian)

7. Basankin I.V., Takhmazian K.K., Afaunov A.A., Ptashnikov D.A., Ponkina O.N., Gavriushenko N.S., Malakhov S.B., Shapovalov V.K. Sposob profilaktiki perelomov smezhnykh pozvonkov pri transpedikuliarnoi fiksatsii na fone osteoporoza [A way of preventing fractures of adjacent 
vertebrae with transpedicular fixation through osteoporosis]. Khirurgiia Pozvonochnika, 2016, vol. 13, no. 3, pp. 8-14. (in Russian)

8. Byvaltsev V.A., Okoneshnikova A.K., Kalinin A.A., Rabinovich S.S. Vzaimosviaz tropizma i anguliatsii dugootrostchatykh sustavov i rezultatov stabiliziruiushchikh operatsii pri degenerativnykh zabolevaniiakh poiasnichnogo otdela pozvonochnika [The relationship between tropism and angulation of facet joints and the results of stabilizing surgeries for degenerative diseases of the lumbar spine]. Khirurgiia Pozvonochnika, 2018, vol. 15 , no. 4 , pp. 70-79. (in Russian)

9. Makirov S.K., Iuz A.A., Dzhakhaf M.T., Gusev S.S. Sovremennye vozmozhnosti zadnei dinamicheskoi stabilizatsii pozvonochnika v profilaktike sindroma smezhnogo urovnia: obzor literatury [Modern possibilities of the spine posterior dynamic stabilization in the prevention of the adjacent level syndrome: review of the literature]. Khirurgiia Pozvonochnika, 2015, vol. 12, no. 1, pp. 46-62. (in Russian)

10. Coursey C.A., Nelson R.C., Boll D.T., Paulson E.K., Ho L.M., Neville A.M., Marin D., Gupta R.T., Schindera S.T. Dual-energy multidetector CT: How does it work, what can it tell us, and when can we use it in abdominopelvic imaging? Radiographics, 2010, vol. 30, no. 4, pp. 1037-1055. DOI: $10.1148 / \mathrm{rg} .304095175$

11. Boll D.T., Patil N.A., Paulson E.K., Merkle E.M., Simmons W.N., Pierre S.A., Preminger G.M. Renal stone assessment with dual-energy multidetector CT and advanced postprocessing techniques: improved characterization of renal stone composition - pilot study. Radiology, 2009, vol. 250, no. 3, pp. 813-820. DOI: 10.1148/radiol.2503080545

12. Aleksanian M.M., Aganesov A.G. Khirurgicheskoe lechenie degenerativnykh stenozov poiasnichnogo otdela pozvonochnika s primeneniem dinamicheskikh implantov [Surgical treatment of degenerative stenoses of the lumbar spine using dynamic implants]. Innovatsionnaia Meditsina Kubani, 2017, no. 3, pp. 34-37. (in Russian)

13. Movshovich I.A., Shotemor Sh.Sh. K voprosu o nestabilnosti pozvonochnika (klassifikatsiia, diagnostika) [On the problem of the spine instability (classification, diagnosis)]. Ortopediia, Travmatologiia i Protezirovanie, 1979, no. 5, pp. 24-29. (in Russian)

14. Prodan A.I., Perepechai O.A., Kolesnichenko V.A., Balan S.I., Chernyshev A.G. Oslozhneniia khirurgicheskogo lecheniia poiasnichnogo spinalnogo stenoza [Complications of surgical treatment of lumbar spinal stenosis]. Khirurgiia Pozvonochnika, 2009, no. 1, pp. 31-37. (in Russian)

15. Byvaltsev V.A., Kalinin A.A., Okoneshnikova A.K., Kerimbaev T.T., Belykh E.G. Fasetochnaia fiksatsiia v kombinatsii s mezhtelovym spondilodezom: sravnitelnyi analiz i klinicheskii opyt novogo sposoba khirurgicheskogo lecheniia patsientov s degenerativnymi zabolevaniiami poiasnichnogo otdela pozvonochnika [Facet fixation combined with interbody spondylodesis: comparative analysis and clinical experience of a new method of surgical treatment of patients with degenerative diseases of the lumbar spine]. Vestnik Rossiiskoi Akademii Meditsinskikh Nauk, 2016, vol. 71 , no. 5, pp. 375-384. (in Russian)

16. Afaunov A.A., Basankin I.V., Mishagin A.V., Kuzmenko A.V., Takhmazian K.K. Revizionnye operatsii v khirurgicheskom lechenii povrezhdenii grudnogo i poiasnichnogo otdelov pozvonochnika [Revision surgeries in surgical treatment of the thoracic and lumbar spine injuries]. Khirurgiia Pozvonochnika, 2015, vol. 12, no. 4, pp. 8-16. (in Russian)

17. Byvaltsev V.A., Stepanov I.A., Aliev M.A., Aglakov B.M., Iusupov B.R., Konovalov N.A. Sravnenie otdalennykh rezultatov primeneniia totalnoi artroplastiki i perednego spondilodeza v lechenii degenerativnogo zabolevaniia sheinykh mezhpozvonkovykh diskov: metaanaliz [Comparison of the long-term results of using total arthroplasty and anterior spondylodesis in treatment of the degenerative disease of cervical interbody discs: metaanalysis]. Voprosy Neirokhirurgii im. N.N. Burdenko, 2019, vol. 83, no. 6, pp. 100-110. (in Russian)

Received: 13.03 .2020

\section{Information about the authors:}

1. Artem E. Krivoshein, M.D., Ph.D., Omsk State Medical University, Omsk, Russian Federation, Clinical medical and surgical center of the Ministry of health of Omsk region, Omsk, Russian Federation, Email: artem.vertebra@rambler.ru

2. Vladimir P. Konev, M.D., Ph.D., Professor, Omsk State Medical University, Omsk, Russian Federation, Email: vpkonev@mail.ru

3. Sergey V. Kolesov, M.D., Ph.D., Professor, Omsk State Medical University, Omsk, Russian Federation, Email: dr-kolesov@yandex.ru

4. Sergey N. Moskovsky, M.D., Ph.D., Omsk State Medical University, Omsk, Russian Federation, Email: Moscow-5@mail.ru

5. Yuriy T. Ignatiev, M.D., Ph.D., Professor,

Omsk State Medical University, Omsk, Russian Federation, Email: ogma.ry@rambler.ru

6. Sergey A. Nikitenko,

Omsk State Medical University, Omsk, Russian Federation, Email: 79139684444@yandex.ru

7. Sergey A. Erofeev, M.D., Ph.D., Professor,

Omsk State Medical University, Omsk, Russian Federation,

Clinical medical and surgical center of the Ministry of health of Omsk region, Omsk, Russian Federation,

Email: esa_rncvto@mail.ru 